\title{
Flexible Lead Bromide Perovskite Solar Cells
}

\author{
Yawen Liu, $^{\dagger}$ Byeong Jo Kim, ${ }^{\dagger}$ Hua Wu, Lin Yuan, Huimin Zhu, Aijie Liu, and Erik M. J. Johansson*
}

Cite This: ACS Appl. Energy Mater. 2020, 3, 9817-9823

Read Online

ABSTRACT: Lead bromide perovskite solar cells (PSCs) have attracted increasing interest partly because of the high open-circuit voltage that has been obtained. Here, we present a simple way to prepare PSCs based on formamidinium lead tribromide, $\mathrm{FAPbBr}_{3}$, by adding methylammonium chloride and methylammonium bromide into the precursor solution. With this method, highquality and pin-hole free perovskite films with large crystal sizes
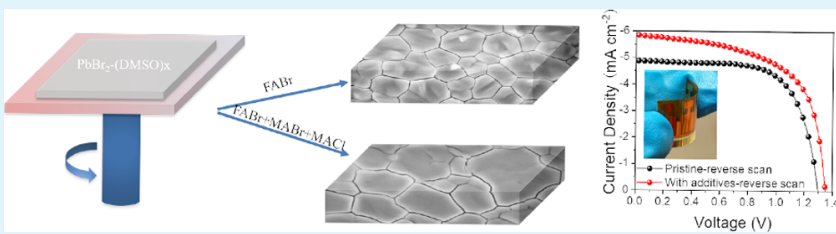
were prepared. These additives result in a power conversion efficiency (PCE) of $7.9 \%$, almost free of hysteresis, for a device on a rigid glass substrate. The first flexible lead bromide PSC is also prepared in this work and the flexible PSC exhibited a high PCE of $5.0 \%$.

KEYWORDS: perovskite solar cells, doping, $\mathrm{FAPbBr}, \mathrm{MABr}, \mathrm{MACl}$, flexible solar cells

\section{INTRODUCTION}

During the last decade, metal halide perovskite solar cells (PSCs) have attracted intense interest because of their very promising photovoltaic properties. In 2009, the first results for a PSC were published and thereafter the power conversion efficiency (PCE) has improved tremendously starting from $3.8 \%$ in the first report to $25.2 \%$ recently reported. ${ }^{1-3}$ More specially, perovskites are expected to be used as nextgeneration solar cells for portable and wearable electronic products because of the possibility of achieving flexibility over curved surfaces, ${ }^{4,5}$ and for flexible PSCs (FPSCs), the PCE is already $19.5 \% .^{6}$ In portable electronic devices, low weight and flexibility are principal priorities. The solar cells that power the most portable electronic devices should ideally be foldable or roll-packable in electronic devices. ${ }^{7}$ In addition, PSCs are also considered to be a good choice in near-space applications, where flexibility and low weight are important. ${ }^{8}$

Although the PCE is a very important factor for solar cells, a high photovoltage may also be very important for technological potential. Minimizing the energy loss of high-energy photons is specifically important to achieve the performance of tandem solar cell devices exceeding the Shockley-Queisser limit. ${ }^{9}$ It was early shown that the bandgap of the perovskite material can be adjusted from 1.55 to $2.3 \mathrm{eV}$ by changing the halide composition in the perovskite from methylammonium lead triiodide, $\mathrm{MAPbI}_{3}$, to tribromide, $\mathrm{MAPbBr}_{3} .{ }^{10}$ The higher bandgap for the lead bromide perovskites also leads to a higher photovoltage. ${ }^{11,12}$ For example, in tandem solar cells ${ }^{13}$ and in specific electrochemical applications, the high open-circuit voltage $\left(V_{\text {oc }}\right)$ may be essential. Furthermore, lead bromide perovskites have the ability to resist humidity and $\mathrm{O}_{2}$, showing a great stability in the ambient air. ${ }^{14,15}$ However, the highly polar methylammonium cation $\left(\mathrm{MA}^{+}\right)$with a dipole moment of 2.29D in $\mathrm{MAPbBr}_{3}$ has a strong affinity for water, which may reduce the stability. ${ }^{16}$ In the perovskite structure, $\mathrm{MA}^{+}$can be replaced by formamidinium $\left(\mathrm{FA}^{+}\right)$, which has a larger ionic radius of $2.79 \AA$ compared to $2.70 \AA$ for $\mathrm{MA}^{+}$. This changes the structure slightly and enhances the thermal stability. ${ }^{17,18}$

However, there are not as many studies on $\mathrm{FAPbBr}_{3}$ as on $\mathrm{MAPbBr}_{3}{ }^{17,19}$ The first reported PSC based on $\mathrm{FAPbBr}_{3}$ showed an efficiency of $6.5 \%$, however, with large hysteresis, which was reported by Hanusch et al. ${ }^{20}$ Furthermore, the mixed solvent of dimethyl sulfoxide (DMSO) $+N, N^{\prime}$-dimethyl formamide (DMF) was used to improve the two-step method of depositing the lead bromide $\left(\mathrm{PbBr}_{2}\right)$ solution in the mesoporous structure, and the efficiency was increased to $7 \% .^{21}$ Subsequently, Arora et al. ${ }^{14}$ used $\mathrm{FAPbBr}_{3}$ as the light absorber and obtained an efficiency of $8.2 \%$ with little hysteresis. They deposited $\mathrm{FAPbBr}_{3}$ on a mesoscopic $\mathrm{TiO}_{2}$ layer by interface engineering. Compared with $\mathrm{TiO}_{2}, \mathrm{SnO}_{2}$ has some advantages in improving efficiency and stability of the solar cells because of the high electron mobility, lower photocatalytic activity, and possibility for easy low-temperature deposition. ${ }^{22,23}$ Zhang et al. ${ }^{24}$ introduced urea as an additive in $\mathrm{SnO}_{2}$-based $\mathrm{FAPbBr}_{3}$ and systematically optimized it to fabricate high-quality $\mathrm{FAPbBr}_{3}$ films.

Considering that the FA-based perovskites have higher thermal stability and broader absorption than MA-based perovskites, it may be advantageous to exchange MA to FA to form $\mathrm{FAPbBr}_{3}$ in solar cell devices. ${ }^{25}$ However, so far, there has been no investigation on the preparation of flexible

Received: June 23, 2020

Accepted: September 4, 2020

Published: September 4, 2020 

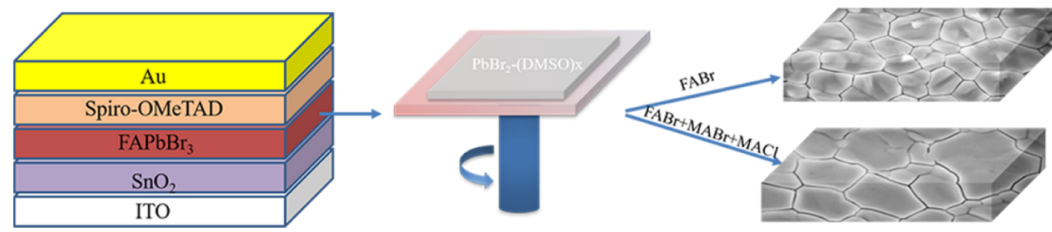

Figure 1. Schematic structure and diagram of the perovskite layer prepared without and with additives.
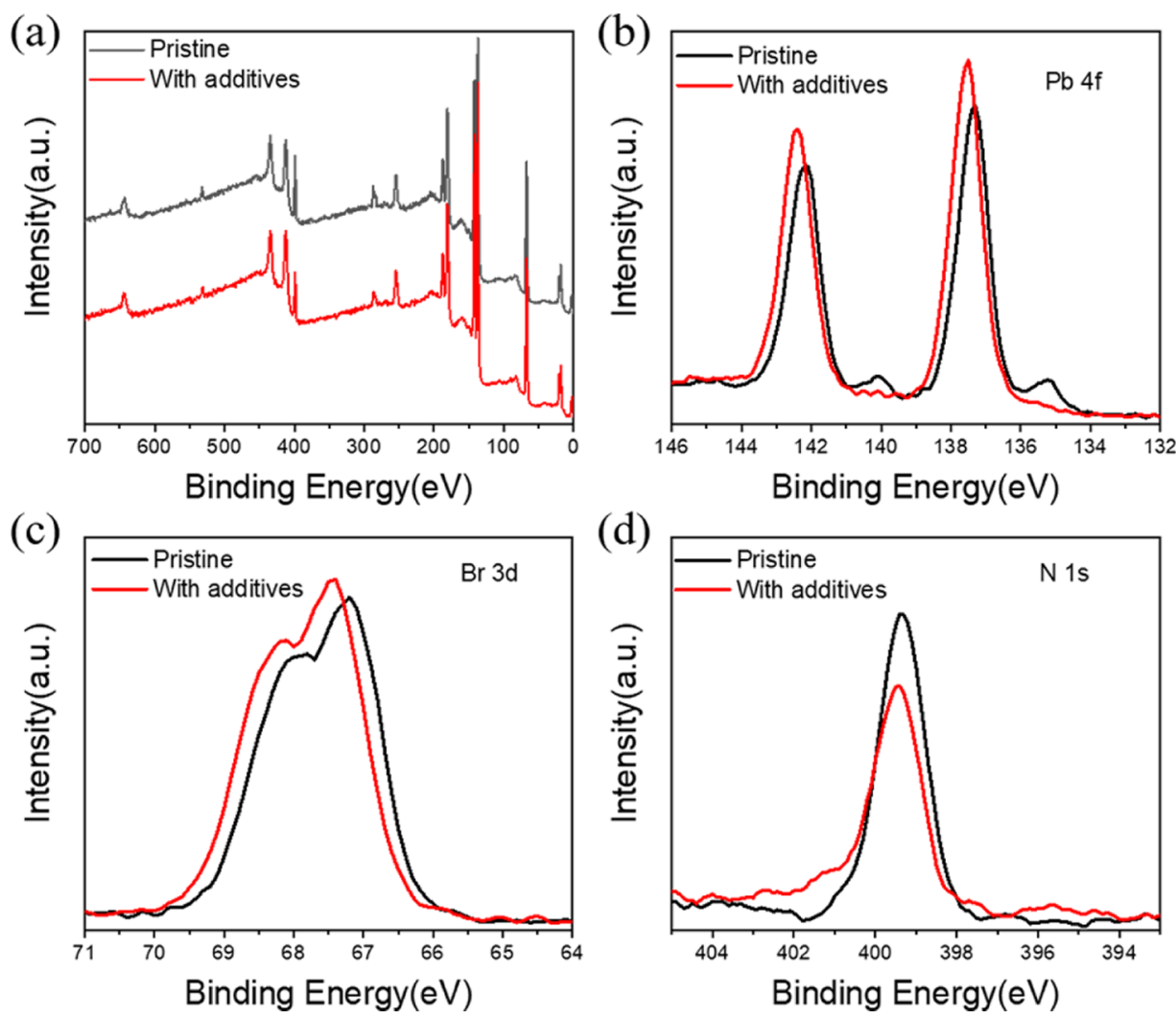

Figure 2. (a) XPS survey spectra of the $\mathrm{FAPbBr}_{3}$ films without and with additives based on rigid substrates. XPS spectrum of (b) Pb 4f, (c) Br 3d, and (d) $\mathrm{N}$ 1s of the $\mathrm{FAPbBr}_{3}$ films without and with additives.

$\mathrm{FAPbBr}_{3}$-based perovskites. Considering the interesting possibilities for flexible solar cell devices in many applications, it is very important to investigate lead bromide perovskite flexible devices, which may be of particularly interest in applications that need a high photovoltage and high stability.

Here, we introduce a two-step method to fabricate $\mathrm{FAPbBr}_{3}$ on a $\mathrm{SnO}_{2}$ electron transport layer. By adding methylammonium bromide $(\mathrm{MABr})$ in the precursor solution, we found that the quality of the perovskite film is improved, ${ }^{26}$ and it can also help us to improve the deficiency of $\mathrm{Br}$, making the $\mathrm{Br} / \mathrm{Pb}$ ratio closer to three in the perovskite film. Methylammonium chloride $(\mathrm{MACl})$ has been reported to enable growth of highquality perovskite films based on $\mathrm{FAPbI}_{3} .{ }^{27}$ In this work, we prepared high-quality $\mathrm{FAPbBr}_{3}$ films on both rigid and flexible substrates by using $\mathrm{MABr}, \mathrm{DMSO}$, and $\mathrm{MACl}$ additives. $\mathrm{MACl}$ may enhance the formation of the $\mathrm{FABr} \cdot \mathrm{PbBr}_{2} \cdot \mathrm{DMSO}$ intermediate and enable the formation of $\mathrm{FAPbCl}_{3-x} \mathrm{Br}_{x}$ perovskite seeds, which can induce perovskite phase transition and improve the growth of the perovskite crystals. ${ }^{28}$ The perovskite films prepared in this way exhibited a larger grain size and higher crystallinity. As a result, an efficiency of $5.0 \%$ for FPSC is obtained, and on a rigid substrate, a PCE of 7.9\%, free of hysteresis, is achieved. Therefore, our work introduces a way to prepare high-quality lead bromide perovskite films and efficient lead bromide PSCs.

\section{EXPERIMENTAL METHODS}

Materials. Colloidal tin oxide solution $\left(\mathrm{SnO}_{2}, 15 \%\right.$ in $\left.\mathrm{H}_{2} \mathrm{O}\right)$ was provided by Alfa Aesar. Indium tin oxide (ITO)-coated polyethylene terephthalate (PET, surface resistivity $60 \Omega /$ sq, $L \times W \times$ thickness 1 $\mathrm{ft} \times 1 \mathrm{ft} \times 5 \mathrm{mil}$, sheet), dimethylformamide (DMF, anhydrous, 99.8\%), bis(trifluoromethanesulfonyl)imide lithium (Li-TFSI), dimethylsulfoxide (DMSO, anhydrous, $\geq 99.9 \%$ ), methanol (HPLC, $\geq 99.9 \%$ ), 4-tert-butylpyridine, acetonitrile (HPLC), and chlorobenzene (anhydrous, 99.8\%) were provided by Sigma-Aldrich $\mathrm{PbBr}_{2}$. $99.99 \%$, trace metals basis was provided by TCI Chemicals. FK209 [tris(2-(1H-pyrazol-1-yl)-4-tert-butylpyridine)-cobalt(III) tris(bis(trifluoromethylsulfonyl)imide), $\mathrm{MACl}, \mathrm{MABr}$, and $\mathrm{FABr}$ were provided by Great cell solar. 2,20,7,70-tetrakis [N,N-di(4-methoxyphenyl) amino]-9,90-spirobifluorene (Spiro-OMeTAD) was purchased from Borun. All the purchased chemicals were used directly.

Device Fabrication. We used a two-step spin-coating method to fabricate the perovskite films. ITO glasses were cleaned by detergent, acetone, 2-propanol, and water for $30 \mathrm{~min}$, respectively. Then, treated with UV/ozone (UVO) for $30 \mathrm{~min}$ before use. The structure of PSCs is $\mathrm{ITO} / \mathrm{SnO}_{2} / \mathrm{FAPbBr}_{3} / \mathrm{Spiro-OMeTAD} / \mathrm{Au}$. We deposited the $\mathrm{SnO}_{2}$ films on the ITO substrates by spin coating the $\mathrm{SnO}_{2}$ solution (diluted with deionized water, the volume ratio of water to $\mathrm{SnO}_{2}$ is 
$4: 1)$ at $3000 \mathrm{rpm}$ for $30 \mathrm{~s}$ and then annealed at $150^{\circ} \mathrm{C}$ on a hotplate for $30 \mathrm{~min}$. After cooling down, they were treated with UVO for 20 min before use. $1.1 \mathrm{M} \mathrm{PbBr}_{2}$ was dissolved in a mixture solution of DMSO and DMF with a volume ratio of 1:9, then it was stirred at 60 wC overnight. The $\mathrm{PbBr}_{2}$ precursor solution was deposited on $\mathrm{SnO}_{2}$ substrates with a spin-coating speed of $1500 \mathrm{rpm}$ for $30 \mathrm{~s}$ and the films were annealed in the glovebox at $60 \mathrm{sC}$ for $2 \mathrm{~min}$. For perovskite preparation without additives, $0.065 \mathrm{~g} F A B r$ dissolved in $1.0 \mathrm{~mL}$ methanol was deposited on the $\mathrm{PbBr}_{2}$ precursor films (2000 rpm, 30 $\mathrm{s})$, then annealed at $140 \mathrm{pC}$ for $25 \mathrm{~min}$ in the air. For the films with additives, $0.065 \mathrm{~g} \mathrm{FABr}, 0.009 \mathrm{~g} \mathrm{MACl}$, and $0.009 \mathrm{~g} \mathrm{MABr}$ were predissolved in $1.0 \mathrm{~mL}$ methanol before spin coating, otherwise the preparation was the same. The preparation of the Spiro-OMeTAD layer was the same as that reported our previous work. ${ }^{29}$ Finally, the $\mathrm{Au}$ electrode $(80 \mathrm{~nm})$ was deposited on the top of the spiroOMeTAD by the thermal evaporator. The preparation of FPSCs was similar to that of rigid devices, just exchanging the glass for the PET substrate.

Characterization. The current density-voltage $(J-V)$ curves were measured using a Wave Labs SINUS-70 solar simulator with UV and IR range extenders. A black aperture with an area of $0.065 \mathrm{~cm}^{2}$ was used during the measurements. External quantum efficiency (EQE) spectra were measured using a xenon lamp (Spectra products ASBXE 175), a potentiostat (PINE AFRDE 5), a LabJack U6, and a monochromator (Spectra Products CM110). X-ray photoelectron spectra (XPS) were recorded by using the instrument PHI Quantera II from Physical Electronics. Scanning electron microscopy (SEM) pictures were taken using the Zeiss LEO 1530/1550 microscope. The time-resolved photoluminescence (TRPL) spectra and the steadystate photoluminescence (SSPL) spectra were recorded on a HORIBA Jobin Yvon Fluorolog station. The ultraviolet-visible (UV-vis) spectra were performed with a HR-2000 Ocean Optics spectrophotometer. X-ray diffraction (XRD) was collected from a Siemens D5000 $\theta-2 \theta$ goniometer with $\mathrm{Cu} \mathrm{K} \alpha(\lambda=1.54051 \AA)$ at room temperature. A Bruker Vertex 70v Fourier transform infrared (FTIR) spectrometer was used to record the IR spectra.

\section{RESULTS AND DISCUSSION}

As shown in Figure 1, we used a two-step spin-coating method to fabricate our perovskite films, which was introduced in the experimental part above. In short, we deposited the $\mathrm{PbBr}_{2}$ precursor solution onto $\mathrm{SnO}_{2}$ substrates and the films were annealed in a nitrogen glovebox at $60 \mathrm{sC}$ for $2 \mathrm{~min}$. For the film preparation without additives, the $\mathrm{FABr}$ solution was deposited on the $\mathrm{PbBr}_{2}$ precursor films. The films were then annealed in air. For the films with additives, the mixed solution with $\mathrm{FABr}, \mathrm{MACl}$, and $\mathrm{MABr}$ was deposited on the $\mathrm{PbBr}_{2}$ precursor films. The films were then annealed in the air similar to the films without additives.

The XPS can be used to study the elementary composition on the surface of the perovskite. ${ }^{30,31}$ To study the effect of the additives in the perovskite, we recorded the XPS spectra. For XPS analysis, all perovskite samples were fabricated on ITO/ $\mathrm{SnO}_{2}$ substrates, which was the same as the preparation of the solar cell devices below. The $\mathrm{Pb} 4 \mathrm{f}, \mathrm{Br} 3 \mathrm{~d}$, and $\mathrm{N} 1$ s spectra were measured to determine the valence state of the lead and the existence of the additives in the final perovskite films. Figure 2 shows the $\mathrm{Pb} 4 \mathrm{f}$ spectra of the films, in which the $\mathrm{Pb}$ 4f spin-orbit splitting peaks $\mathrm{Pb} 4 \mathrm{f}_{7 / 2}$ and $\mathrm{Pb} 4 \mathrm{f}_{5 / 2}$ were located around 138 and $143 \mathrm{eV}$, respectively. ${ }^{32,33}$

It is noteworthy that two smaller peaks can be observed in the $\mathrm{Pb}$ 4f XPS spectra of the perovskite film without additives, located at around 135 and $140 \mathrm{eV}$, which are because of the presence of metallic $\mathrm{Pb}^{0}{ }^{34}$ Watson et al. analyzed the sources of $\mathrm{Pb}^{0}$ using XPS analysis of perovskites. ${ }^{32}$ The metallic $\mathrm{Pb}^{0}$ defects act as the centers for nonradiative recombination, ${ }^{35}$ and are unfavorable for the transport and collection of photogenerated charge carriers. ${ }^{36}$ In contrast, for the sample with additives, these two peaks disappeared. It implies that there is a reduction in the content of metallic lead, which improves the photovoltaic performance. In the $\mathrm{Br} 3 \mathrm{~d}$ spectrum, the $\mathrm{Br} 3 \mathrm{~d}$ signals that correspond to $3 \mathrm{~d}_{3 / 2}$ and $3 \mathrm{~d}_{5 / 2}$ peaks can be observed. The $\mathrm{Pb} 4 \mathrm{f}$ peaks in the $\mathrm{Pb} 4 \mathrm{f}$ spectrum and the $\mathrm{Br} 3 \mathrm{~d}$ peaks in the $\mathrm{Br} 3 \mathrm{~d}$ spectrum were shifted to higher binding energies for the film with additives, indicating a slight shift of the Fermi level in the perovskite films with additives. Comparing the intensities of the core-level peaks in the two films, the $\mathrm{Pb} 4 \mathrm{f}$ and $\mathrm{Br} 3 \mathrm{~d}$ peaks increased slightly for the perovskite with additives (Figure $2 \mathrm{~b}, \mathrm{c}$ ), while the peak of $\mathrm{N} 1 \mathrm{~s}$ decreased slightly compared to that of the pristine sample (Figure 2d). The atomic ratios between iodine, lead, and nitrogen are listed in Table $\mathrm{S} 1$. The $\mathrm{Br} / \mathrm{Pb}$ ratio increased from 2.54 to 2.71 and the $\mathrm{N} / \mathrm{Pb}$ ratio decreased from 2.28 to 2.03, when additives were included in the film. The film with additives, therefore, shows $\mathrm{Br} / \mathrm{Pb}$ and $\mathrm{N} / \mathrm{Pb}$ ratios closer to the ideal ratios. In addition, in order to check the presence of $\mathrm{Cl}$ in the perovskite films, we also measured the $\mathrm{Cl} 2 \mathrm{p}$ core level (Figure S1). There was no evidence of $\mathrm{Cl}$ atoms at the surfaces of the perovskite films, which may be because of the evaporation of chlorine during the annealing process. There may, however, still be a very small amount of $\mathrm{Cl}$, which may be too small to be detected.

FTIR spectroscopy was employed to further investigate our samples. As shown in Figure S2, we measured the FTIR spectrum of $\mathrm{FAPbBr}_{3}, \mathrm{FAPbBr}_{3}$ with additives, $\mathrm{FABr}, \mathrm{MABr}$, and $\mathrm{MACl}$. The FTIR spectrum of $\mathrm{FAPbBr}_{3}$ without additives and the $\mathrm{FABr}$ samples showed similar $\mathrm{N}-\mathrm{H}$ stretch peaks, which are different from those of $\mathrm{MABr}$ and $\mathrm{MACl}$. However, the $\mathrm{CH}_{3}$ bend peaks were observed in $\mathrm{MABr}, \mathrm{MACl}$, and $\mathrm{FAPbBr}_{3}$ with additives. This indicates that some amount of $\mathrm{MA}$ is included in the $\mathrm{FAPbBr}_{3}$ film with the additives.

We used the SEM to investigate the surface morphologies of the perovskite films. From the SEM images in Figure 3a,b, the perovskites in all samples had good coverage and no obvious pinholes. The cross-sectional images in Figure $3 c$ also suggest that the perovskite layer was evenly deposited on the ITO/ $\mathrm{SnO}_{2}$, free of pinholes. After adding $\mathrm{MABr}$ and $\mathrm{MACl}$, the grain size increased from 1.2 to $1.6 \mu \mathrm{m}$, indicating an improved crystallization, which is consistent with XRD analysis, as will be discussed below. It is, therefore, clear that the additives affect the size of the $\mathrm{FAPbBr}_{3}$ grains. The thickness of the $\mathrm{FAPbBr}_{3}$ film with additives is around $630 \mathrm{~nm}$, as seen in Figure 3c. A similar thickness was also found for the pristine $\mathrm{FAPbBr}_{3}$ film, as can be observed in Figure S3.

To further investigate the influence of additives on the perovskite film, XRD measurements, UV-vis absorption, SSPL, and TRPL were used to analyze the perovskite films. From Figure $4 \mathrm{a}$, the intensities of the peaks for the perovskite film with additives were stronger than those of the pristine perovskite film, indicating the enhanced crystallization of the perovskite film. ${ }^{35}$ The 001 peak of the perovskite film with additives moves slightly toward higher angles, which may be attributed to the larger ionic radius of $\mathrm{FA}^{+}$than that of $\mathrm{MA}^{+} .^{17,18}$ The results, therefore, suggest the presence of MA in the perovskite prepared with additives. ${ }^{37}$ Taking into account the influence of $\mathrm{Cl}$ on the perovskite crystal growth and the adjustment of the morphology of the active layer, ${ }^{27}$ the additive of $\mathrm{MACl}$ may help to enhance the crystallization of the perovskite. Similar XRD results were also found for the 

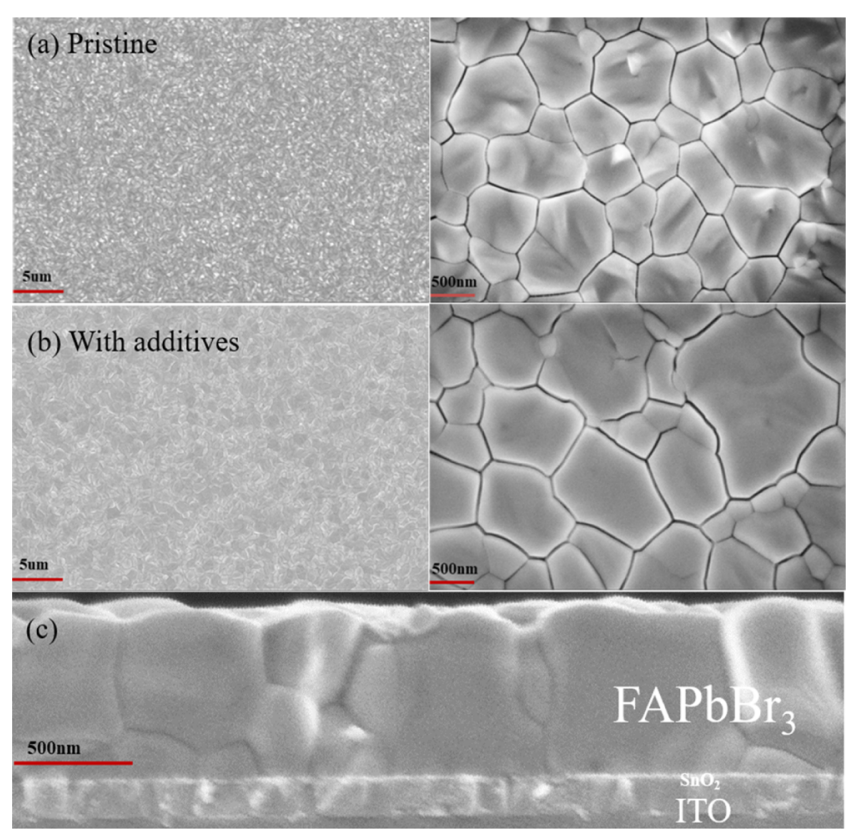

Figure 3. SEM top view micrographs of the $\mathrm{FAPbBr}_{3}$ films (a) without and (b) with additives, on the rigid glass/ITO/ $\mathrm{SnO}_{2}$ substrate. Below: cross-section of the $\mathrm{FAPbBr}_{3}$ film with additives on the rigid glass/ITO/ $\mathrm{SnO}_{2}$ substrate (c).

$\mathrm{FAPbBr}_{3}$ films on the PET/ITO/SnO $\mathrm{S}_{2}$ substrate in Figure S4. The diffraction peaks at $2 \theta$ around $26^{\circ}$ are attributed to the PET substrate. ${ }^{38}$

The UV-vis absorption spectra of the $\mathrm{FAPbBr}_{3}$ films without and with additives show sharp absorption peaks at the band edge near $530 \mathrm{~nm}$ in Figure 4b. Notably, for the perovskite with the additives, the absorbance onset edge shows a small blue shift. This means that the optical bandgap of the perovskite film was slightly increased, which may be because of the higher bandgap of $\mathrm{MAPbBr}_{3}{ }^{39}$ The SSPL intensity for the $\mathrm{FAPbBr}_{3}$ films on the glass/ITO/ $\mathrm{SnO}_{2}$ substrate in Figure $4 \mathrm{c}$ increases with additives, and the SSPL spectra of the $\mathrm{FAPbBr}_{3}$ films on the PET/ITO/ $\mathrm{SnO}_{2}$ substrate (Figure S5) also show the same trend. Below, we show that a better PCE is obtained for the device with additives, which may be because of the higher degree of radiative recombination, leading to a high short-circuit current density $\left(J_{\text {sc }}\right)$ and $V_{\text {oc }}{ }^{40}$ For the TRPL spectra in Figure 4d, we used a biexponential equation of $y=y_{0}$ $+A_{1} \exp \left(-\left(x-x_{0}\right) / \tau_{1}\right)+A_{2} \exp \left(-\left(x-x_{0}\right) / \tau_{2}\right)$ to fit the PL decay curves. The $\tau_{1}$ and $\tau_{2}$ time constants represent fast and slow decay, respectively. ${ }^{41} \tau_{1}$ is usually attributed to nonradiative trap-mediated recombination, while $\tau_{2}$ is related to radiative recombination. ${ }^{42}$ As listed in Table 1 , with additives,

Table 1. Fitted Results of the TRPL Curves in Figure 4d

\begin{tabular}{lrcccc}
\multicolumn{1}{c}{ devices } & $\tau_{1}(\mathrm{~ns})$ & $\tau_{2}(\mathrm{~ns})$ & $A_{1}$ & $A_{2}$ & $\tau_{\text {ave }}(\mathrm{ns})$ \\
pristine & 70.0 & 5.0 & 1250 & 1150 & 38.9 \\
with additives & 140.0 & 8.0 & 1200 & 1200 & 74.0 \\
\hline
\end{tabular}

$\tau_{2}$ becomes longer $(8.0 \mathrm{~ns})$, which suggests an improvement in radiative recombination and in good agreement with the SSPL results. We used the equation of $\tau_{\text {ave }}=\tau_{1} A_{1} /\left(A_{1}+A_{2}\right)+\tau_{2} A_{2} /$ $\left(A_{1}+A_{2}\right)$ to calculate the average time constant $\left(\tau_{\text {ave }}\right) .{ }^{41}$ The $\mathrm{FAPbBr}_{3}$ film prepared with additives exhibits longer $\tau_{\text {ave }}(74.0$ ns), which may explain the higher $V_{\text {oc }}$ values.

The $J-V$ curves of the PSCs are shown in Figure 5 and the device parameters are shown in Table 2. For the rigid devices, the champion $\mathrm{FAPbBr}_{3}$ device without additives showed a PCE of $6.6 \%$, with a $V_{\text {oc }}$ of $1.34 \mathrm{~V}$, a $J_{\text {sc }}$ of $7.86 \mathrm{~mA} \mathrm{~cm}^{-2}$, and a fill factor (FF) of 62.8, which are similar to those of pristine $\mathrm{FAPbBr}_{3}-\mathrm{PSCs}$ in other reports. ${ }^{14,21}$ The best $\mathrm{FAPbBr}_{3}$ device
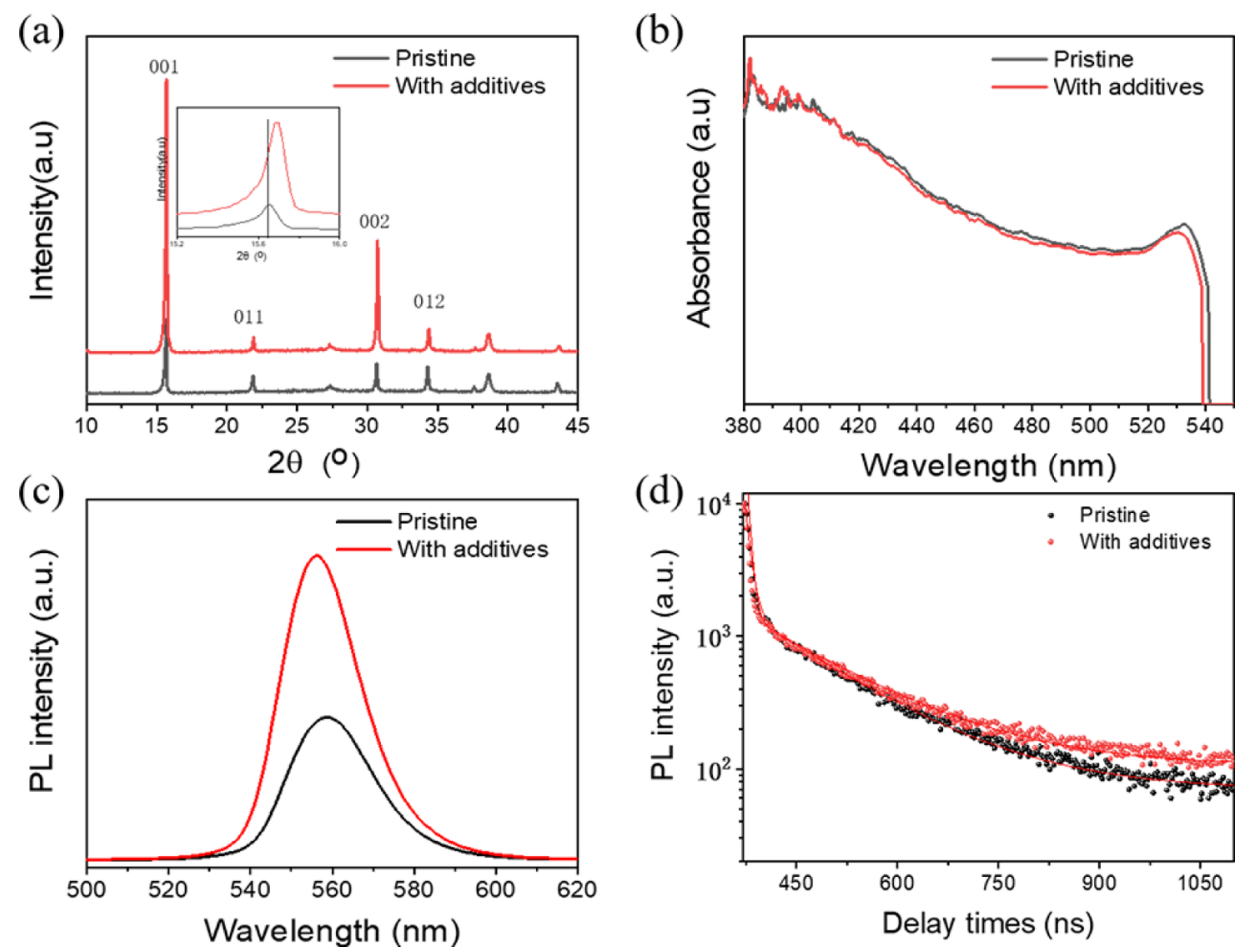

Figure 4. (a) XRD patterns, (b) UV-vis spectra, (c) SSPL, and (d) TRPL spectra of the $\mathrm{FAPbBr}_{3}$ films on rigid glass/ITO/SnO ${ }_{2}$ substrates. 
(a)

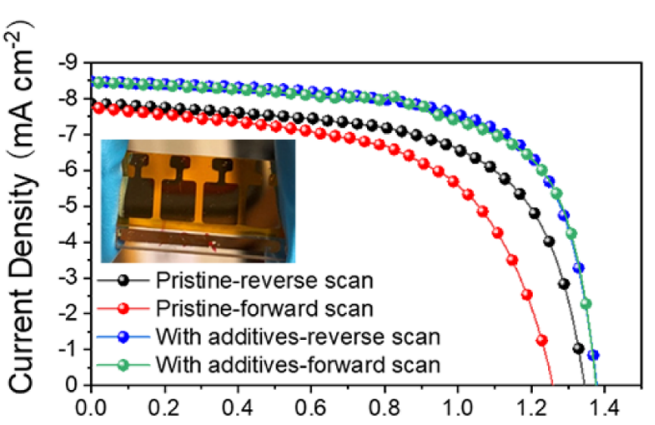

(c)

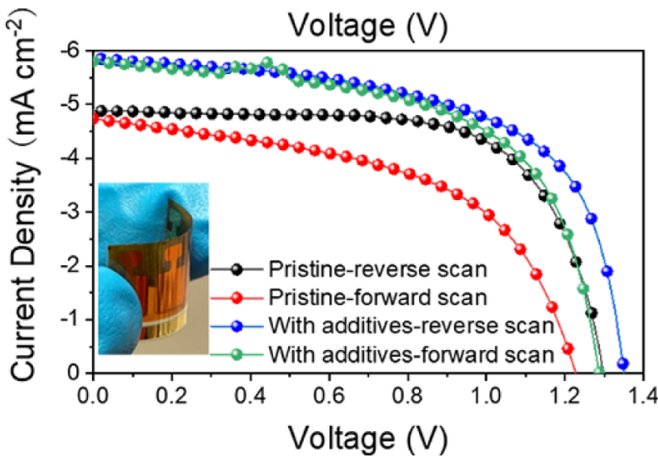

(b)

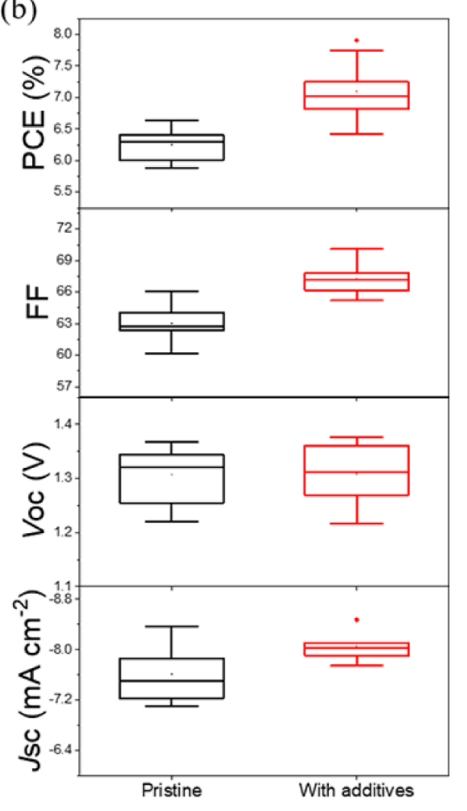

Figure 5. (a) $J-V$ characteristics (champion cells), (b) statistics photovoltaic parameter (10 devices) of PCE, fill FF, $V_{\mathrm{oc}}$ and $J_{\mathrm{sc}}$ of FAPbBr 3 -PSCs without and with additives based on the rigid substrate. (c) $J-V$ characteristics (champion cells) of $\mathrm{FAPbBr}_{3}-\mathrm{PSCs}$ without and with additives based on the flexible substrate. The data were recorded under AM $1.5 \mathrm{G}$ one sun illumination $\left(100 \mathrm{~mW} \mathrm{~cm}^{-2}\right)$. A black mask with an aperture area of $0.065 \mathrm{~cm}^{2}$ was used during measurement.

Table 2. Device Parameters for Champion PSCs without and with Additives

\begin{tabular}{|c|c|c|c|c|c|}
\hline \multicolumn{2}{|l|}{ device } & $\begin{array}{l}\text { PCE } \\
(\%)\end{array}$ & FF & $\begin{array}{c}J_{\mathrm{sc}} \\
\left(\mathrm{mA} \mathrm{cm}^{-2}\right)\end{array}$ & $\begin{array}{l}V_{\text {oc }} \\
(\mathrm{V})\end{array}$ \\
\hline \multirow[t]{2}{*}{$\begin{array}{l}\text { pristine on the rigid } \\
\text { substrate }\end{array}$} & $\begin{array}{c}\text { reverse } \\
\text { scan }\end{array}$ & 6.6 & 62.8 & -7.86 & 1.34 \\
\hline & $\begin{array}{l}\text { forward } \\
\text { scan }\end{array}$ & 5.6 & 57.8 & -7.76 & 1.25 \\
\hline \multirow[t]{2}{*}{$\begin{array}{l}\text { with additives on the } \\
\text { rigid substrate }\end{array}$} & $\begin{array}{c}\text { reverse } \\
\text { scan }\end{array}$ & 7.9 & 67.7 & -8.48 & 1.37 \\
\hline & $\begin{array}{l}\text { forward } \\
\text { scan }\end{array}$ & 7.7 & 66.6 & -8.46 & 1.37 \\
\hline \multirow[t]{2}{*}{$\begin{array}{l}\text { pristine on the flexible } \\
\text { substrate }\end{array}$} & $\begin{array}{l}\text { reverse } \\
\text { scan }\end{array}$ & 4.3 & 67.9 & -4.89 & 1.29 \\
\hline & $\begin{array}{c}\text { forward } \\
\text { scan }\end{array}$ & 3.1 & 52.9 & -4.74 & 1.22 \\
\hline \multirow[t]{2}{*}{$\begin{array}{l}\text { with additives on the } \\
\text { flexible substrate }\end{array}$} & $\begin{array}{l}\text { reverse } \\
\text { scan }\end{array}$ & 5.0 & 60.5 & -5.93 & 1.37 \\
\hline & $\begin{array}{l}\text { forward } \\
\text { scan }\end{array}$ & 4.5 & 59.4 & -5.87 & 1.30 \\
\hline
\end{tabular}

with additives exhibited a PCE of $7.9 \%$ with very little hysteresis.

The devices with or without additives both showed a good long-term stability. After 70 days, their efficiency was only reduced by around $12 \%$ in the dry box (Figure S6). The PCE of the flexible device was improved from 4.3 to $5.0 \%$ by adding the additives. As shown in Figure $5 b$, it is confirmed that the additives can help to improve the photovoltaic performance by measuring the device parameters of a batch of 10 devices. We noticed that the devices with additives have a higher average PCE, FF, $V_{\mathrm{oc}}$ and $J_{\mathrm{sc}}$ for the devices in comparison to the pristine devices $(7.1 \pm 0.81$ to $6.3 \pm 0.43,67.3+3.05$ to 62.5 $\pm 3.91,1.31 \pm 0.07$ to $1.30 \pm 0.06$, and $8.06 \pm 0.4$ to $7.61 \pm$ 0.70 , respectively).
As shown in Figure 6, EQE was monitored for the PSCs without and with additives based on rigid and flexible

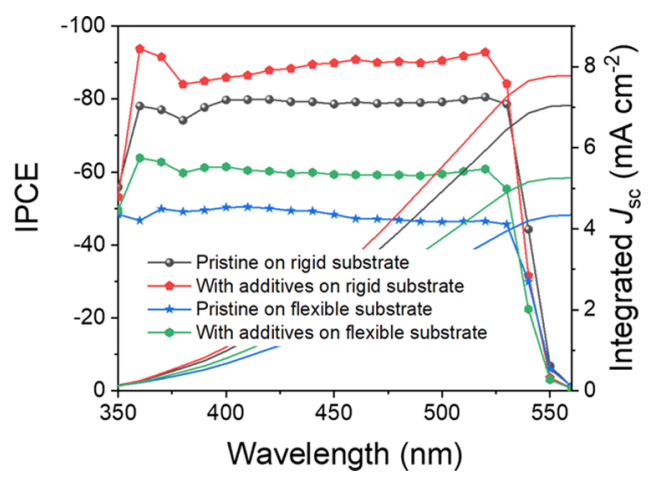

Figure 6. EQE spectra of PSCs without and with additives based on rigid and flexible substrates.

substrates. The trend from the EQE measurements for the different devices is consistent with the $J-V$ measurements above. It can be seen that the EQE for the device with additives on a rigid (glass) substrate shows a very high EQE, close to the maximal possible (without antireflection coating). We can, therefore, conclude that the additives play a very important role in the photocurrent properties of the perovskite film.

\section{CONCLUSIONS}

In conclusion, we introduce a simple and effective way to obtain a high-quality lead bromide perovskite by adding $\mathrm{MABr}$ and $\mathrm{MACl}$ to the preparation of the films. We use a combination of methods to study the various factors that improve photovoltaic performance. The SEM and XRD results 
indicate the increased perovskite crystal size, and higher crystallinity for the films with additives. The PL measurements demonstrate improved optical properties for the perovskite with additives. The rigid PSCs with additives exhibited a PCE of $7.9 \%$, with very little hysteresis. The FPSC with additives showed a PCE of $5.0 \%$, and it is the first flexible device based on the $\mathrm{FAPbBr}_{3}$ material.

\section{ASSOCIATED CONTENT}

\section{SI Supporting Information}

The Supporting Information is available free of charge at https://pubs.acs.org/doi/10.1021/acsaem.0c01473.

Characterization of the work, cross-sectional SEM, FTIR spectra of the pristine device, XPS survey spectra, atomic ratio of different elements obtained by XPS, and normalized PCE of the PSCs (PDF)

\section{AUTHOR INFORMATION}

\section{Corresponding Author}

Erik M. J. Johansson - Department of Chemistry-Ångström, Physical Chemistry, Uppsala University, 75120 Uppsala, Sweden; (1) orcid.org/0000-0001-9358-8277;

Email: erik.johansson@kemi.uu.se

\section{Authors}

Yawen Liu - Department of Chemistry-Ångström, Physical Chemistry, Uppsala University, 75120 Uppsala, Sweden

Byeong Jo Kim - Department of Chemistry-Ångström, Physical Chemistry, Uppsala University, 75120 Uppsala, Sweden

Hua Wu - Department of Chemistry-Ångström, Physical Chemistry, Uppsala University, 75120 Uppsala, Sweden

Lin Yuan - Department of Chemistry-Ångström, Physical Chemistry, Uppsala University, 75120 Uppsala, Sweden

Huimin Zhu - Department of Chemistry-Ångström, Physical Chemistry, Uppsala University, 75120 Uppsala, Sweden

Aijie Liu - Department of Chemistry-Ångström, Physical Chemistry, Uppsala University, 75120 Uppsala, Sweden

Complete contact information is available at:

https://pubs.acs.org/10.1021/acsaem.0c01473

\section{Author Contributions}

${ }^{\dagger}$ Y.L. and B.J.K. contributed equally.

\section{Notes}

The authors declare no competing financial interest.

\section{ACKNOWLEDGMENTS}

The authors acknowledge the financial support obtained from the Swedish Energy Agency, ÅForsk, Swedish Research Council (VR), and Olle Engkvist Foundation.

\section{REFERENCES}

(1) Kojima, A.; Teshima, K.; Shirai, Y.; Miyasaka, T. Organometal Halide Perovskites as Visible-Light Sensitizers for Photovoltaic Cells. J. Am. Chem. Soc. 2009, 131, 6050-6051.

(2) Jung, H. S.; Park, N.-G. Perovskite Solar Cells: From Materials to Devices. Small 2015, 11, 10-25.

(3) https://www.nrel.gov/pv/assets/images/efficiency-chart.png (Accessed Aug 31, 2020).

(4) Feng, J.; Zhu, X.; Yang, Z.; Zhang, X.; Niu, J.; Wang, Z.; Zuo, S.; Priya, S.; Liu, S.; Yang, D. Record Efficiency Stable Flexible Perovskite Solar Cell Using Effective Additive Assistant Strategy. Adv. Mater. 2018, 30, 1801418.
(5) Popoola, I. K.; Gondal, M. A.; Qahtan, T. F. Recent progress in flexible perovskite solar cells: Materials, mechanical tolerance and stability. Renewable Sustainable Energy Rev. 2018, 82, 3127-3151.

(6) Huang, K.; Peng, Y.; Gao, Y.; Shi, J.; Li, H.; Mo, X.; Huang, H.; Gao, Y.; Ding, L.; Yang, J. High-Performance Flexible Perovskite Solar Cells via Precise Control of Electron Transport Layer. Adv. Energy Mater. 2019, 9, 1901419.

(7) Zhang, J.; Zhang, W.; Cheng, H.-M.; Silva, S. R. P. Critical review of recent progress of flexible perovskite solar cells. Mater. Today 2020, 1369-7021.

(8) Tu, Y.; Xu, G.; Yang, X.; Zhang, Y.; Li, Z.; Su, R.; Luo, D.; Yang, W.; Miao, Y.; Cai, R.; Jiang, L.; Du, X.; Yang, Y.; Liu, Q.; Gao, Y.; Zhao, S.; Huang, W.; Gong, Q.; Zhu, R. Mixed-cation perovskite solar cells in space. Sci. China: Phys., Mech. 2019, 62, 974221.

(9) McMeekin, D. P.; Sadoughi, G.; Rehman, W.; Eperon, G. E.; Saliba, M.; Hörantner, M. T.; Haghighirad, A.; Sakai, N.; Korte, L.; Rech, B.; Johnston, M. B.; Herz, L. M.; Snaith, H. J. A mixed-cation lead mixed-halide perovskite absorber for tandem solar cells. Science 2016, 351, 151-155.

(10) Noh, J. H.; Im, S. H.; Heo, J. H.; Mandal, T. N.; Seok, S. I. Chemical Management for Colorful, Efficient, and Stable InorganicOrganic Hybrid Nanostructured Solar Cells. Nano Lett. 2013, 13, 1764-1769.

(11) Edri, E.; Kirmayer, S.; Cahen, D.; Hodes, G. High Open-Circuit Voltage Solar Cells Based on Organic-Inorganic Lead Bromide Perovskite. J. Phys. Chem. Lett. 2013, 4, 897-902.

(12) Xing, G.; Mathews, N.; Sun, S.; Lim, S. S.; Lam, Y. M.; Grätzel, M.; Mhaisalkar, S.; Sum, T. C. Long-Range Balanced Electron- and Hole-Transport Lengths in Organic-Inorganic $\mathrm{CH}_{3} \mathrm{NH}_{3} \mathrm{PbI}_{3}$. Science 2013, 342, 344-347.

(13) Albrecht, S.; Saliba, M.; Correa Baena, J. P.; Lang, F.; Kegelmann, L.; Mews, M.; Steier, L.; Abate, A.; Rappich, J.; Korte, L.; Schlatmann, R.; Nazeeruddin, M. K.; Hagfeldt, A.; Grätzel, M.; Rech, B. Monolithic perovskite/silicon-heterojunction tandem solar cells processed at low temperature. Energy Environ. Sci. 2016, 9, 81-88.

(14) Arora, N.; Dar, M. I.; Abdi-Jalebi, M.; Giordano, F.; Pellet, N.; Jacopin, G.; Friend, R. H.; Zakeeruddin, S. M.; Grätzel, M. Intrinsic and Extrinsic Stability of Formamidinium Lead Bromide Perovskite Solar Cells Yielding High Photovoltage. Nano Lett. 2016, 16, 71557162.

(15) Zheng, X.; Chen, B.; Yang, M.; Wu, C.; Orler, B.; Moore, R. B.; Zhu, K.; Priya, S. The Controlling Mechanism for Potential Loss in CH3NH3PbBr3 Hybrid Solar Cells. ACS Energy Lett. 2016, 1, 424430.

(16) Frost, J. M.; Butler, K. T.; Brivio, F.; Hendon, C. H.; van Schilfgaarde, M.; Walsh, A. Atomistic Origins of High-Performance in Hybrid Halide Perovskite Solar Cells. Nano Lett. 2014, 14, 25842590.

(17) Meng, L.; Yao, E.-P.; Hong, Z.; Chen, H.; Sun, P.; Yang, Z.; Li, G.; Yang, Y. Pure Formamidinium-Based Perovskite Light-Emitting Diodes with High Efficiency and Low Driving Voltage. Adv. Mater. 2017, 29, 1603826.

(18) Eperon, G. E.; Stranks, S. D.; Menelaou, C.; Johnston, M. B.; Herz, L. M.; Snaith, H. J. Formamidinium lead trihalide: a broadly tunable perovskite for efficient planar heterojunction solar cells. Energy Environ. Sci. 2014, 7, 982-988.

(19) Yang, X.; Zhang, X.; Deng, J.; Chu, Z.; Jiang, Q.; Meng, J.; Wang, P.; Zhang, L.; Yin, Z.; You, J. Efficient green light-emitting diodes based on quasi-two-dimensional composition and phase engineered perovskite with surface passivation. Nat. Commun. 2018, 9,570 .

(20) Hanusch, F. C.; Wiesenmayer, E.; Mankel, E.; Binek, A.; Angloher, P.; Fraunhofer, C.; Giesbrecht, N.; Feckl, J. M.; Jaegermann, W.; Johrendt, D.; Bein, T.; Docampo, P. Efficient Planar Heterojunction Perovskite Solar Cells Based on Formamidinium Lead Bromide. J. Phys. Chem. Lett. 2014, 5, 2791-2795.

(21) Arora, N.; Dar, M. I.; Hezam, M.; Tress, W.; Jacopin, G.; Moehl, T.; Gao, P.; Aldwayyan, A. S.; Deveaud, B.; Grätzel, M.; Nazeeruddin, M. K. Photovoltaic and Amplified Spontaneous 
Emission Studies of High-Quality Formamidinium Lead Bromide Perovskite Films. Adv. Funct. Mater. 2016, 26, 2846-2854.

(22) Correa Baena, J. P.; Steier, L.; Tress, W.; Saliba, M.; Neutzner, S.; Matsui, T.; Giordano, F.; Jacobsson, T. J.; Srimath Kandada, A. R.; Zakeeruddin, S. M.; Petrozza, A.; Abate, A.; Nazeeruddin, M. K.; Grätzel, M.; Hagfeldt, A. Highly efficient planar perovskite solar cells through band alignment engineering. Energy Environ. Sci. 2015, 8, $2928-2934$.

(23) Jiang, Q.; Zhang, L.; Wang, H.; Yang, X.; Meng, J.; Liu, H.; Yin, Z.; Wu, J.; Zhang, X.; You, J. Enhanced electron extraction using $\mathrm{SnO}_{2}$ for high-efficiency planar-structure $\mathrm{HC}\left(\mathrm{NH}_{2}\right)_{2} \mathrm{PbI}_{3}$-based perovskite solar cells. Nat. Energy 2016, 2, 16177.

(24) Zhang, Y.; Liang, Y.; Wang, Y.; Guo, F.; Sun, L.; Xu, D. Planar $\mathrm{FAPbBr}_{3}$ Solar Cells with Power Conversion Efficiency above $10 \%$. ACS Energy Lett. 2018, 3, 1808-1814.

(25) Turren-Cruz, S.-H.; Hagfeldt, A.; Saliba, M. Methylammoniumfree, high-performance, and stable perovskite solar cells on a planar architecture. Science 2018, 362, 449-453.

(26) Zhang, L.; Zhang, X.; Xu, X.; Tang, J.; Wu, J.; Lan, Z. $\mathrm{CH} 3 \mathrm{NH} 3 \mathrm{Br}$ Additive for Enhanced Photovoltaic Performance and Air Stability of Planar Perovskite Solar Cells prepared by Two-Step Dipping Method. Energy Technol. 2017, 5, 1887-1894.

(27) Xie, F.; Chen, C.-C.; Wu, Y.; Li, X.; Cai, M.; Liu, X.; Yang, X.; Han, L. Vertical recrystallization for highly efficient and stable formamidinium-based inverted-structure perovskite solar cells. Energy Environ. Sci. 2017, 10, 1942-1949.

(28) Wu, C.; Wang, D.; Zhang, Y.; Gu, F.; Liu, G.; Zhu, N.; Luo, W.; Han, D.; Guo, X.; Qu, B.; Wang, S.; Bian, Z.; Chen, Z.; Xiao, L. $\mathrm{FAPbI}_{3}$ Flexible Solar Cells with a Record Efficiency of $19.38 \%$ Fabricated in Air via Ligand and Additive Synergetic Process. Adv. Funct. Mater. 2019, 29, 1902974.

(29) Jesper Jacobsson, T.; Correa-Baena, J.-P.; Pazoki, M.; Saliba, M.; Schenk, K.; Grätzel, M.; Hagfeldt, A. Exploration of the compositional space for mixed lead halogen perovskites for high efficiency solar cells. Energy Environ. Sci. 2016, 9, 1706-1724.

(30) Deepa, M.; Ramos, F. J.; Shivaprasad, S. M.; Ahmad, S. Unraveling the Role of Monovalent Halides in Mixed-Halide Organic-Inorganic Perovskites. ChemPhysChem 2016, 17, 913-920.

(31) Sveinbjörnsson, K.; Kyi Thein, N. K.; Saki, Z.; Svanström, S.; Yang, W.; Cappel, U. B.; Rensmo, H.; Boschloo, G.; Aitola, K.; Johansson, E. M. J. Preparation of mixed-ion and inorganic perovskite films using water and isopropanol as solvents for solar cell applications. Sustain. Energ.Fuels 2018, 2, 606-615.

(32) McGettrick, J. D.; Hooper, K.; Pockett, A.; Baker, J.; Troughton, J.; Carnie, M.; Watson, T. Sources of $\mathrm{Pb}(0)$ artefacts during XPS analysis of lead halide perovskites. Mater. Lett. 2019, 251, 98-101.

(33) Liu, M.; Zhong, G.; Yin, Y.; Miao, J.; Li, K.; Wang, C.; Xu, X.; Shen, C.; Meng, H. Aluminum-Doped Cesium Lead Bromide Perovskite Nanocrystals with Stable Blue Photoluminescence Used for Display Backlight. Adv. Sci. 2017, 4, 1700335.

(34) Lindblad, R.; Bi, D.; Park, B.-w.; Oscarsson, J.; Gorgoi, M.; Siegbahn, H.; Odelius, M.; Johansson, E. M. J.; Rensmo, H. Electronic Structure of $\mathrm{TiO}_{2} / \mathrm{CH}_{3} \mathrm{NH}_{3} \mathrm{PbI}_{3}$ Perovskite Solar Cell Interfaces. J. Phys. Chem. Lett. 2014, 5, 648-653.

(35) Bi, D.; Yi, C.; Luo, J.; Décoppet, J.-D.; Zhang, F.; Zakeeruddin, S. M.; Li, X.; Hagfeldt, A.; Grätzel, M. Polymer-templated nucleation and crystal growth of perovskite films for solar cells with efficiency greater than 21\%. Nat. Energy 2016, 1, 16142.

(36) Liu, C.; Huang, Z.; Hu, X.; Meng, X.; Huang, L.; Xiong, J.; Tan, L.; Chen, Y. Grain Boundary Modification via F4TCNQ To Reduce Defects of Perovskite Solar Cells with Excellent Device Performance. ACS Appl. Mater. Interfaces 2018, 10, 1909-1916.

(37) Zhao, J.-S.; Wang, H.-Y.; Yu, M.; Hao, M.-Y.; Yuan, S.; Qin, Y.; Fu, L.-M.; Zhang, J.-P.; Ai, X.-C. Charge carrier recombination dynamics in a bi-cationic perovskite solar cell. Phys. Chem. Chem. Phys. 2019, 21, 5409-5415.

(38) Liu, X.; Du, H.; Wang, P.; Lim, T.-T.; Sun, X. W. A highperformance UV/visible photodetector of $\mathrm{Cu} 2 \mathrm{O} / \mathrm{ZnO}$ hybrid nano- films on SWNT-based flexible conducting substrates. J. Mater. Chem. C 2014, 2, 9536-9542.

(39) Wu, Y.; Chen, W.; Chen, G.; Liu, L.; He, Z.; Liu, R. The Impact of Hybrid Compositional Film/Structure on Organic-Inorganic Perovskite Solar Cells. Nanomaterials 2018, 8, 356.

(40) Shin, G. S.; Kim, S. G.; Zhang, Y.; Park, N. G. A Correlation between Iodoplumbate and Photovoltaic Performance of Perovskite Solar Cells Observed by Precursor Solution Aging. Small Methods 2020, 4, 1900398.

(41) Liu, Y.; Liu, Z.; Lee, E.-C. High-Performance Inverted Perovskite Solar Cells Using Doped Poly(triarylamine) as the Hole Transport Layer. Appl. Energy Mater. 2019, 2, 1932-1942.

(42) Zhang, Y.; Kim, S.-G.; Lee, D.; Shin, H.; Park, N.-G. Bifacial stamping for high efficiency perovskite solar cells. Energy Environ. Sci. 2019, 12, 308-321. 